Examination of knowledge management and market orientation, innovation and organizational performance: Insights from telecom sector of Pakistan

Irfan Ullah

Bilal Mirza

Iqra University, Islamabad, Pakistan

Abdul Rauf Kashif

Institute of Southern Punjab, Multan, Pakistan

Farrukh Abbas

Allama Iqbal Open University, Pakistan

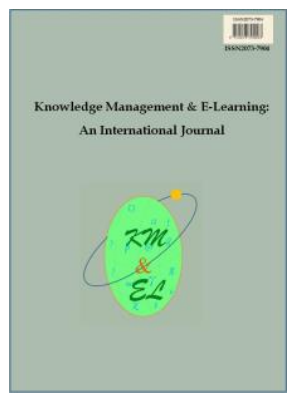

Knowledge Management \& E-Learning: An International Journal (KM\&EL) ISSN 2073-7904

Recommended citation:

Ullah, I., Mirza, B., Kashif, A. R., \& Abbas, F. (2019). Examination of knowledge management and market orientation, innovation and organizational performance: Insights from telecom sector of Pakistan. Knowledge Management \& E-Learning, 11(4), 522-551. https://doi.org/10.34105/j.kmel.2019.11.027 


\title{
Examination of knowledge management and market orientation, innovation and organizational performance: Insights from telecom sector of Pakistan
}

\author{
Irfan Ullah* \\ Department of Business Administration \\ Iqra University, Islamabad, Pakistan \\ E-mail: irfanullahtarar1979@gmail.com
}

\section{Bilal Mirza}

Department of Business Administration Iqra University, Islamabad, Pakistan

E-mail: bilal.mirza@iqraisb.edu.pk

\author{
Abdul Rauf Kashif \\ Department of Business Administration \\ Institute of Southern Punjab, Multan, Pakistan \\ E-mail: kashifrauf365@gmail.com
}

\section{Farrukh Abbas}

Department of Business Administration Allama Iqbal Open University, Pakistan

E-mail: safmi_26@yahoo.com

*Corresponding author

\begin{abstract}
Knowledge Management and Market Orientation have become buzzwords today owing to their importance for enhancing organizational performance. Innovation has become the strategic need of organizations at present in order to contend with the extreme market competition. The objective of this research was to examine the impact of knowledge management orientation on a firm's performance with the mediating role of organizational innovation and market orientation. Data was collected through personal surveybased questionnaire. Based on a survey of 343 employees from Telecom Sector of Pakistan, this study applied Structural Equation Modeling (SEM) Technique to observe the research model. The results of the study demonstrate that knowledge management orientation plays an affirmative role in the promotion of organizational performance. The organizational innovation has significant impact on the performance of the organization. It was also revealed that there is positive effect of market orientation on organizational performance. Moreover, innovation and market orientation were observed to have mediating role in the knowledge management orientation-organizational performance linkage. As, the global phenomenon exposes that if the knowledge management, market orientation and innovation in relation to performance are being practiced, then the results are promising, driving extensively in a constructive way as validated
\end{abstract}


by the literature review. Consequently, this research is one the first attempts in Pakistan towards the perspective i.e. knowledge management orientation, organizational innovation, market orientation in relation to the performance of an organization. It will further contribute towards the local academic and viable arena of Pakistan.

Keywords: Knowledge management orientation; Organizational innovation; Market orientation; Performance

Biographical notes: Irfan Ullah is a doctoral candidate of Business Administration, Iqra University Islamabad, Pakistan. He has been involved in the research areas of human resource management, CSR, knowledge management, ethical leadership, organizational performance and intellectual capital development.

Dr. Bilal Mirza is Head of Business Administration Department, Iqra University, Islamabad Campus, Pakistan. His research activities have been in the multi-disciplinary areas of knowledge management, organizational innovation, leadership development, and organizational performance.

Abdul Rauf Kashif is Senior Lecturer at Institute of Southern Punjab, Department of Business Administration, Multan, Pakistan. His research interests include motivation, economics, accounting \& finance and human capital development.

Farrukh Abbas has completed MS Management Sciences from Allama Iqbal Open University, Islamabad, Pakistan. He is interested in studying high performance work practices, employee motivation, employee agility, thriving at work, voice behavior, knowledge management and organizational innovation.

\section{Introduction}

\subsection{Background}

The generation and accessibility of new and existing knowledge demonstrate a remarkable challenge and opportunity to organizations attempting to compete in a global arena. At the beginning of the current decade when the competitive atmosphere went through a major revolution due to globalization, businesses have increased their exploration for a policy that will provide them a sustainable competitive benefit. Such policies usually need that the organizations always differentiate their products and process, that is, organizations must continually be innovative (Brewer \& Brewer, 2010; Manfredi Latilla, Frattini, Messeni Petruzzelli, \& Berner, 2018). In such circumstance, where innovation in products and process is considered as an indispensable requirement for the business success and survival, concentration to market orientation and change to a firm invoked a lot of interest of scholars and business associates (Li, Huang, \& Tsai, 2009; Shujahat et al., 2019).

The literature on strategic management identifies innovation as an important initiator for organizations to generate value and maintain competitive advantage in the progressive compound and quickly changing atmosphere (Zoghi, Mohr, \& Meyer, 2010). Organizations with greater innovativeness will be winning in answering to altering the 
environment and in developing new capability that permits them to attain improved output. Innovation plans lean to rely a lot on peoples' proficiency, knowledge, and dedication as significant inputs in the process of value creation (Navarro, Acedo, Robson, Ruzo, \& Losada, 2010).

Establishing an innovation environment needs suitable strategies, practices and policies with respect to individuals and work. Effective knowledge management orientation in terms of organizational memory, knowledge absorption, knowledge sharing and knowledge receptivity increases an organization's competence in establishing new goods, services, and management structures, guiding to better novel results (Liu, Gong, Zhou, \& Huang, 2017; Rahman, Daud, \& Raman, 2018). As innovative businesses are characterized by greater ambiguity and inconsistency, businesses need to keep focus on market orientation to improve the business performance (Herrera, Muñoz-Doyague, \& Nieto, 2010; Maughan, 2012).

\subsection{Problem identification and contribution of the study}

Today's problems cannot be resolved with yesterday's solutions. The ecological situations are so complex, vibrant, and uncertain that organizations cannot guarantee their extensive existence without innovation (Tidd \& Bessant, 2018). The key device, which can benefit the firms with this, is the wisdom and knowledge factor (Emerson \& Berge, 2018). It prepares the organization for change as well as the competitive advantage for the existence and growth of the organization (Farooq \& Vij, 2018). There was a time when organizations were acting under a stable and constant atmosphere. It was almost feasible for them to forecast the future, so that business managers and supervisors could supervise and manage the company within certain circumstances. However, changes in science \& technology, politics, economy, and society persuaded the organizational procedures. Business leaders observed that they must recognize knowledge as an important fact. To succeed in realizing an improved future, they should educate their employees to share knowledge within the organization (Adams, Jeanrenaud, Bessant, Denyer, \& Overy, 2016; Li et al., 2009).

Knowledge is believed as the basic mode of prosperity and wealth creation and the most valuable significant strength for the achievement of organizational goal (Martinez-Martinez, Cegarra-Navarro, Garcia-Perez, \& Wensley, 2019; Riege, 2007). Knowledge management is becoming a progressive issue for business interests. The objectives of knowledge management are stressed by some researchers (Eger, 2018; Liu et al., 2017). Those research scholars believe that the knowledge management can be considered as knowledge of organizational management. This particular school of thought provides more contemplation on the data warehouse, file management, data mining and knowledge base concepts (de Guimarães, Severo, \& de Vasconcelos, 2018). Moreover, it highlights the institutional value of knowledge management system structurally. In some situations, they outlook knowledge management as about the management of facts and uphold that management of knowledge is transmitting true knowledge for true individuals at right time also it can serve for organizations to produce maturity for effectiveness in decision-making. A number of other scholars believe that organizational knowledge is considered as abilities and strategically resourceful assets that are important, uncommon and hard to copy and replacement (Hussein, Rahayu, \& Prabandari, 2017; Ireland, Reutzel, \& Webb, 2005).

Market orientation is important for a new project to assist the exploitation of innovative and prevailing knowledge to find out market openings (Kasim, Ekinci, Altinay, \& Hussain, 2018; Wiklund \& Shepherd, 2003). Conversely, organization with originality 
has a trend to permit new thoughts and innovation, and supplementary enhance the commitment in the development of new products, processes and services (Lin \& Lee, 2005). The development of new goods and process entails extensive and intensive knowledge undertakings. Organizations with market orientation lean to rely on individuals' knowledge and expertise as important efforts in the knowledge progression. Knowledge management orientation is an outline of more rendering the knowledge and skill to construct worth and improve business performance (Fang \& Chang, 2016; Navarro et al., 2010). The study confirms that efficient knowledge management orientation helps knowledge publication and replace obligatory in the origination procedure, and more increases firm's productivity through the development of new thoughts and abilities (Argote, McEvily, \& Reagans, 2003; Van Raaij \& Stoelhorst, 2008). Consequently, knowledge management orientation may perform a critical part in assisting and promoting performance of a firm (Chen \& Huang, 2009; Chen \& Liang, 2011).

The previous research focused on empirically testing the association between knowledge management orientation (KMO) and organizational performance with the mediating effect of market orientation (Wang, Hult, Ketchen Jr, \& Ahmed, 2009), and the role of organizational innovation was overlooked. Testing the association of KMO with market orientation, organizational innovation and organizational performance is a novel field in this research (Masa'deh, Shannak, Maqableh, \& Tarhini, 2017; Zack, McKeen, \& Singh, 2009). The present study was carried out in order to fill this literature gap. Our research activities are contributing to the existing literature by the role of KMO with respect to the performance of an organization and the role of market orientation and organizational innovation in the telecom sector of Pakistan, Fig. 1 portrays the research model.

The main theme of previous research of Wang et al. (2009) was to check the impact of knowledge management orientation on the performance of an organization. However, the mediating role of organizational innovation was ignored. There is not enough empirical research showing how knowledge management orientation binds an organization in innovation and market orientation, and ultimately increase the performance of the organization, particularly with an orientation to Pakistan. Moreover, previous study was performed in developed regions. Therefore, contemporary research will also contribute and support in the domain of knowledge management orientation, innovation, market orientation in relation to business performance from a developing country stance like Pakistan.

\subsection{Problem statement}

According to Farooq (2018), Pakistan telecom sector revenues through the first twoquarters FY 2017-18 touched PkRs. 235.5 billion, revealed the Economic Survey of Pakistan 2017-18. The telecom firms in brutal competition need to emphasize on their knowledge management practices along with innovation and market orientation. These firms face the issue of brutal completion. In order to compete in the competitive environment, a business desires to focus on all components of the business, utilizing the effectiveness of all its resources. These resources play a key role in any company's innovation process that in turn guides to organizational performance. The factors linked to organizational performance have been examined in the contemporary research. Dynamics of innovation and market orientation in brutal competition have made KMO and organizational performance more important for the knowledge-based firms. Although, knowledge management orientation and organizational performance have been examined 
in the prior study. However, mediating role of market orientation and innovation has not been investigated. This lack understanding of roles of innovation and market orientation may leave the KMO stranded ineffective. Thus, after the holistic understanding of KMO towards organizational performance with mediator innovation and market orientation will be able to better plan and implement KMO practices encompassing innovation and market orientation for the sake enhanced performance of the organization.

\subsection{Significance and rationale of the study}

Knowledge is important for the modern firms in a progressively more intricate social, economic atmosphere of business, particularly for the knowledge organization. Research reveals that knowledge management orientation is an organizational strategy, which guarantees proper knowledge is transmitted to the employees at the right time, assists the persons for sharing, and put into practice interests, ultimately civilizing the rationale of organizational performance. Other researchers consider knowledge management orientation from the behavior of organization (Wofford, 2006; Zheng, Yang, \& McLean, 2010). The main research paradigm of knowledge management orientation is the construction of a knowledge management model. Nonaka, Toyama, and Konno (2000) categorized the model of knowledge management into three classes: Organizational Performance Based Model (OPBM), Knowledge Based Model (KBM) and Knowledge Tool Based Model (KTBM). The ultimate rationale of knowledge management orientation is the improvement in business performance. The research narrates that if an organization wants to compete in the market, then it ought to be market oriented with fully exploitation of resources (Chen, Li, Evans, \& Arnold, 2017). The knowledge management orientation is a consistent and valid gauge for knowledge managementoriented attitudes (Certo, Moss, \& Short, 2009; Rahman et al., 2018). It reveals an outcome about knowledge management as creating organization abilities, improving organizational performance and offering a useful device for the businesses to occasionally evaluate their knowledge management implementation.

\subsection{Study objectives}

The major objective of contemporary study is to find out factors, which improve organizational performance and intended to identify the influence of KMO on organizational performance with the mediating mechanism of organizational innovation and market orientation.

\section{Literature review and research framework}

\subsection{Knowledge management orientation (KMO)}

Different scholars have provided different definitions of knowledge management orientation. For example, Lin and Lee (2005) defined KMO as an intended process to control the acquiring, sharing and applying knowledge as a firm asset to promote invention enactment. Wang et al. (2009) established KMO like a firm's comparative tendency to build on its attained intelligence (organizational information memory), the tendency for allocation of information (sharing of knowledge), incorporate (knowledge absorption) and open for new insight (knowledge receptivity). In the contemporary study, four constructs of KMO have been adopted, which are being explained below: 


\subsubsection{Organizational memory $(O M)$}

Different scholars have defined organizational memory in different words. Moorman and Miner (1997) in their study defined organizational memory as the attained knowledge that is discovered from earlier knowledge, which might be carried out to tolerate on business decisions. The most fundamental denotation of a firm's memory is information, which appears form the history of a business and is utilized for decision-making (Brewer \& Brewer, 2010).

\subsubsection{Knowledge sharing $(K S)$}

The term knowledge sharing may be defined as the process, which allocates knowledge among all the people involving in the development undertakings (Lin \& Lee, 2005). According to Tsai (2002), knowledge sharing (KS) is referring to as the transmit of knowledge, technology and skill between the departments, divisions and subdivisions of the organization.

\subsubsection{Knowledge absorption (KA)}

Knowledge Absorption (KA) is the capability of a business to identify the worth of new insight, its incorporation and application. It consists of two important practices: knowledge discovery and utilization (Van Den Bosch, Volberda, \& de Boer, 1999).

\subsubsection{Knowledge receptivity $(K R)$}

Popper and Lipshitz (1998) narrate that knowledge receptivity reveals an easiness through which latest thoughts are taken up in the organization. This notion submits the amount to which new thoughts are evaluated in accordance with their value and removed from the personality and condition of the provider.

\subsection{Organizational performance $(O P)$}

The measurement of performance is not simple for businesses with complex goals of production, profitability, employee satisfaction, development, growth, CSR and capability to adjust to the ever-changing atmosphere among other goals. Organizational performance has been conventionally conceived in terms of monetary processes. However, some researchers have anticipated an extensive concept that integrates nonfinancial measurements involving market share, quality of products and services, and business image.

The earlier study shows that professed measurements of organizational performance may be a realistic alternate of object measurements of business performance (Chang \& Huang, 2005; Shin \& Konrad, 2017), and have a considerable relationship with object measurements of monetary performance. Moreover, cross-industry business performance is determined by outside financial components (Bamberger, Biron, \& Meshoulam, 2014), therefore, subjective assessment can be even more suitable than object measures. In addition to the trouble in attaining object measures of organizational performance, it recommends soliciting business leaders to evaluate their own organization's performance comparative to others in the same area. To diminish the results of random error, scholars have recommended the use of several substances to evaluate organizational performance. Known this situation, the author in this research has 
selected to utilize multiple objects to evaluate the performance of the businesses to be investigated. These objects are related to quality of services and products, competitive market share, production cost, comparative performance with respect to rivals and comparative performance according to the industry.

\subsection{Knowledge management orientation and organizational performance}

Organizations with innovative capacity have a trend to permit novel and new thoughts, and supplementary enhance the commitment in the development of new products or processes ( $\mathrm{Li}$ et al., 2009). The development of new goods and process entails intensive and extensive knowledge activities. Organizations with market orientation lean to rely on individuals' knowledge and expertise as important inputs in the knowledge process. Knowledge management orientation is a trend of more rendering the knowledge and skill to construct value and improve business performance (Manfredi Latilla et al., 2018; Navarro et al., 2010; Zheng et al., 2010). The study verifies that effective knowledge management orientation helps awareness communication and interchange obligatory in the innovation process, and more increases firm's productivity through the development of innovative ideas and abilities (Argote et al., 2003; Castaneda \& Durán, 2018; Van Raaij \& Stoelhorst, 2008). Thus, knowledge management may play a critical part in assisting and promoting performance of a firm (Chen \& Liang, 2011; Eger, 2018).

Knowledge management orientation performs a vital role in supporting and promoting organizational performance. The newly obtained knowledge, interacting with the accessible knowledge may transform knowledge stock of an organization, and improve the depth and breadth of knowledge available to the organization, thus improving the prospective for innovative results (Birkinshaw, Hamel, \& Mol, 2008). The knowledge-based view recommends that the knowledge management movement shall improve an organization's capability to achieve its role (Chen et al., 2017). Organizations with superior competence to obtain outside and inside knowledge will decrease insecurity and accomplish a greater number of managerial and technical distinctiveness (Damanpour, Szabat, \& Evan, 1989; Emerson \& Berge, 2018). Therefore, it is stated that KMO has a positive relationship with organizational performance. Hence, it can be hypothesized that:

Hypothesis 1: An organization's knowledge management orientation is positively related to organizational performance.

\subsection{Organizational innovation}

Organizational innovation, involving the development of new goods or services and new management system, is promising as an essential source of affirmed viable benefit. Organizations showing a greater intensity of knowledge management orientation practice a learning outcome that may enhance their capability in decreasing idleness, replying quickly to modify, and developing innovative thoughts and improvement (Scarbrough, 2003). An innovation is like a device, which is used by almost all organizations for generation of profitability and other benefits. It cannot only increase the business of firms, but also improve vitality, adaptability and improvement in the performance. An organization ought to pay more concentration on development of innovative capability and make stronger its competitive dominion to face the challenge from other competitive organizations and environmental uncertainty (Maughan, 2012; Mitrega, Forkmann, Zaefarian, \& Henneberg, 2017). 
According to Chen et al. (2017), the innovation progression is the growth and performance of latest thoughts and views by the individuals who are concerned with transforming the central or organizational field in collaboration with others. Krammer (2017) says that it is the use of new procedural knowledge to present innovative goods or services to end users and customers. Hence, it may be said that the innovation is considered as any new technique in the businesses that may contain equipment, goods, services, processes, strategies, policies and projects (Lin, 2007). In other words, innovation is the creation of innovative wisdom and promotion of thoughts to assist the creation of new products and services, improving the organizational processes, and producing market-based goods and services (Baregheh, Rowley, \& Sambrook, 2009).

Now a days, organizational innovation is necessary for innovative awareness and positive differential advantage to the business sectors (Liu et al., 2017). The practices and ways of the organizational innovation are tremendously versatile. These can be premeditated from two main parts; number one is the extensiveness of innovation that contains managerial procedures, structures, rules, existing services and products. Second thing is creativity and innovation depth, which is a further important concern. It defines the employees' level of inspiration, which affects long run services and productivity. Damanpour and Gopalakrishnan (2001), and, Damanpour and Evan (1984) exclaimed that there are two main types of organizational innovation; administrative innovation and technological innovation. Technological innovation comprises product innovation and process innovation (Chen et al., 2017). The results originated from earlier study explain that organizational innovation is categorized into three main types that are product innovation, process innovation and administrative innovation. According to Tan and Nasurdin (2010); Mavondo, Chimhanzi, and Stewart (2005); Damanpour and Gopalakrishnan (2001); Damanpour and Evan (1984), the organizational innovation can be categorized into three main types, number one products innovations, number two processes innovations and number three administrative type innovations. According to Cooper (1998), processes innovation, products innovation and administrative type innovations are central ancestors for engineering firms. Moreover, those are more likely to make reasonable advantages for business for value addition, and problem resolutions. Consequently, the firm's innovation is working for a multi-categorized containing of these particular main types of innovation.

The idea of organizational innovation was first time introduced by Schumpeter, 1934 (Schumpeter, 1934). Subsequently, different researchers have presented different explanations for this notion. Therefore, organizational innovation is conceived as a key dynamic in the survival of an organization. Usually, the speculative debate associated to the organizational innovation is some adaptations of two substantial approaches. These approaches are the purpose-oriented approach and the subject-oriented approach. The purpose-oriented approach focuses on the innovation itself, while the subject-oriented approach focuses on the issues like industry, country, companies, and groups, which have produced and executed the innovation developments (Ballot, Fakhfakh, Galia, \& Salter, 2015).

\subsection{Organizational innovation and organizational performance}

The increasing rapidity of organizational innovation process improves the developments in market share, and quality of product and services. Organizational innovation can guide to better organizational performance. Brewer and Brewer (2010) narrated that firm's innovation that contains technical and administrative innovation, might have impact on the performance of an organization in best practices of organizations. Significant 
relationships among firms' innovativeness, dynamics, and achievements were observed during the survey conducted in the previous studies (Mitrega et al., 2017; Subramanian \& Nilakanta, 1996). Some other scholars had checked encouraging effects of up to date innovations on firms' performance (Hansen, Mors, \& Løvås, 2005; Schulz \& Jobe, 2001). Organizational innovation may be categorized according to different criterion. According to the radicalism of innovation, the innovation process can be categorized into two types such as radical and incremental. Radical innovation generates basic alterations in the business activities and signifies an apparent departure from present patterns; while incremental innovation consequence in a smaller amount of exit (Zoghi et al., 2010).

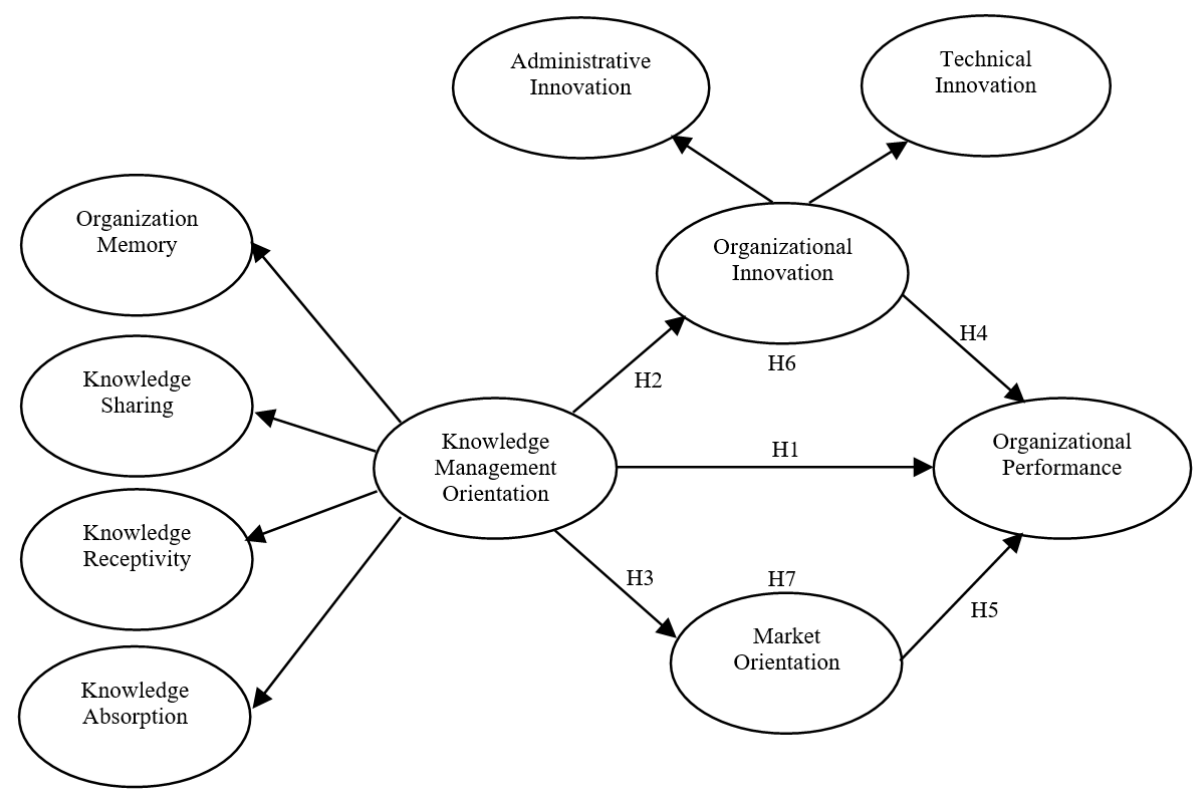

Fig. 1. Proposed model of the study

According to the dual-core model, an innovation is comprised of administrative and technical innovation. An administrative innovation refers to latest strategies, practices, policies, procedures and structures of the organizations. The technical innovation denotes to the introduction of the latest developments or superior services or goods, which can create winning situations in the markets already existing.

The innovations' development might be a source of contributions to the performance of an organization (Gunday, Ulusoy, Kilic, \& Alpkan, 2011; Pérez-Luño, Valle Cabrera, \& Wiklund, 2007). That is to say, that innovator has the potential to generate markets, outline client preferences, and even modify the elementary behavior of customers (Hyun, 2018; Zhou, 2006), that in brief directs to higher benefits. By studying the literature as discussed above, we indicate that new activities represent a significant competence that increases the performance of an organization. Therefore, the following hypothesis can be presented:

Hypothesis 2: Organizational innovation is positively related to organizational performance. 


\subsection{Market orientation}

Market orientation is defined as activities involving the creation of market intelligence that are relevant to the operations of an organization, distribution of effective and valuable knowledge to create proper assessment with the response of market's supportive design. As execution of strategies, elements such as rivals might affect performance of an organization with the ability to present the valuable importance for customers. A business operator's beneficial importance was offering to its customers and price arrangement in producing the worth restrains its performance (Morgan, Kaleka, \& Katsikeas, 2004).

\subsubsection{Market orientation and organizational performance}

Market orientation is important for a new project to assist the exploitation of existing and new knowledge to grab opportunities from the market (Wiklund \& Shepherd, 2003). Conversely, organizations with innovative capacity have a trend to permit novelty and new thoughts. There has been a considerable amount of efficient research showing the link between performance of an organization and market orientation. In the study of Renko, Carsrud, and Brännback (2009), it has been suggested that market orientation enhances the organizational performance to a considerable extent. A number of external forces, like weaker economy, market instability and competition might moderate the association between market orientation and organizational performance. The atmospheric circumstance of a business will more likely manipulate its stage of market orientation. Businesses in more aggressive and energetic atmosphere are anticipated to subsist further market oriented. Consequently, an association between business performance and market orientation relies on organizational environmental character. Firms, which work with fast changing technology, might be capable to gain a competitive benefit through technological novelty mutually with the market orientation.

Market orientation is considerably significant to enable organizations to recognize the marketplace and develop suitable goods and services to meet the requirements of the consumers (Liu \& White, 1997; Wang et al., 2009). Market orientation ensures a consumer-focused policy for market information-based creation, subsequently harmonized, inter-functional market activities to attain enduring victory of the organization. There have been major movements in the improvement of a market orientation since 1980s and much critical attempts have been dedicated to defining, conceptualize, and operationalize theories of market orientation (Renko et al., 2009).

Definitely, if an organization is to be advanced, management should develop organizational landscapes, which represent a perfect 'learning orientation', an idea that rotates about the development of new insights, knowledge, and correlated cultural and behavioral change. Market orientation has been incorporated as an appropriate variable in theoretic outlines trying to describe strategic organizational structures and dynamics (Chen \& Huang, 2009; Devece, Llopis-Albert, \& Palacios-Marqués, 2017; Zoghi et al., 2010).

A lot of research on the association between business performance and market orientation has been done (Kohli, Jaworski, \& Kumar, 1993). Nevertheless, the outcomes of those studies show deviation concerning the route of the relationships, antecedent and mediator. As prior research shows the optimistic association between firm performance and market orientation, several studies accounted non-significant or inadequate relationship. In the study of Bhuian (1997), conducted in Saudi Arabia, there was not a considerable association between organizational performance and market orientation. 
To explain valuable concept of a firm's performance and market orientation, Kirca, Jayachandran, and Bearden (2005) prepared Meta-analysis as an evaluation about predecessors with effects related to organizational performance and market orientation. This might be said that the research of Kirca et al. (2005) was a more inclusive analysis work on the market orientation. This study was based on mismatched massive database involving 418 consequences from 130 free samples accounted 114 researches. The findings showed that market orientation had an affirmative impact on business performance, for example overall organizational performance, earnings, sale and market share. Moreover, the research showed considerable relationships among market orientation along with high-level administration prominence, market-based compensation organism and interdepartmental link (Kirca et al., 2005).

Forgoing in view, following hypothesis may be put forwarded:

Hypothesis 3: Market orientation is positively related to organizational performance.

\subsection{Knowledge management orientation and organizational innovation}

The organization memory is considered as the addition of knowledge resources and assets (Kingston \& Macintosh, 2000) also a one-mode conduct for the actions of a business using precedent knowledge and information efficiency improvement ( $\mathrm{Li}$ et al., 2009). Accordingly, organizational memory offers the foundation for organizational innovation related activities. This assists the people to build up innovative products and accomplish innovation related new activities, supports the management for the establishment of new views and technology, and encouragement for management's level.

Tsai (2001) established that the innovation of an organization would be endorsed when sharing and co-operation are durable amongst the various divisions. The knowledge sharing is a beginning position of knowledge link between group and individuals (Nonaka \& Takeuchi, 1995). The creation of knowledge is a spiraling technique of positive relations among tacit and explicit knowledge (Castaneda \& Durán, 2018). The firms have the potential to innovate promptly, but only by receiving rapidly, the necessary knowledge can become the innovation resource. The tactic for obtaining the desired knowledge source is the sharing of knowledge. The knowledge sharing process is vital for improvement of the innovation concert (Donate \& de Pablo, 2015; Rahman et al., 2018; Teece, 1998), and it is an essential forecaster of the completion of actions related to outsourcing (Lee, 2001; Shujahat et al., 2019). The sharing of knowledge performs a vital role in the procedure of innovation development ability in knowledge-intensive organizations (Liao, Fei, \& Chen, 2007). Accordingly, KMO may perform a key role in assisting and promoting innovation (Chen \& Huang, 2009; Hwang \& Xie, 2018).

The pioneering study of Cohen and Levinthal (1990) has observed absorption ability as a new outlook on innovation and learning. Liu and White (1997) found that innovations are motivated by association between an investment in absorption capability (most prominently, research \& development of employees) and investments in new awareness' source. Zahra and George (2002) argued that there are merely those who actually have ability of absorption, which can acquire competitive improvement through technological innovation and product development. From a network point of view, Tsai (2001) explained that the capability of absorption about firm's components is not merely optimistic and openly persuade performance and innovation, although influences obliquely innovation and its performance by interface with unit networks location. According to Cohen and Levinthal (1990), knowledge absorption highlights the 
achievement, and recognition of new intelligence and wisdom, whereas information utilization hub on the deployment about accessible knowledge.

The meaning of knowledge receptivity is a positive approach towards innovative thoughts and assistance of interior uptake and execution. It is generally referred that the more knowledge receptive is the firm, the more accommodating and accepting is innovative in thought, coordination, structure and approaches of operation (Donate \& de Pablo, 2015). Therefore, knowledge receptivity is strongly related to technical and administrative innovations. Keeping in view the above, it can be hypothesized that KMO is associated with organizational innovation. Hence:

Hypothesis 4: An organization's knowledge management orientation is positively related to organizational innovation.

\subsection{Knowledge management orientation and market orientation}

A rigorous market orientation is considered as important for comparative differential advantage (Hussein et al., 2017; Narver \& Slater, 1990). Nevertheless, efficacious implementation of a market orientation (the degree to which market orientation is illustrated strongly) depends on the support of an organizational internal culture (Deshpande \& Webster Jr, 1989; Wang, Ahmed, \& Rafiq, 2008). In this regard, an organization's KMO (or lack thereof) influences the value of the organization's market orientation exertions (Day, 1994; Wang et al., 2009). For instance, lack of the shared beliefs inherent in knowledge management orientation is probable to hamper the activity configurations, which are such a vital factor of the market orientation paradox (Davis, 1984; Farooq \& Vij, 2018). In this circumstance, an organization's lack of KMO impedes and destabilizes the efficiency of its actions of creating and propagating external intelligence attained about the market and its capability to exploit the intelligence to counter to the market (Emerson \& Berge, 2018). On the other hand, a strong knowledge management orientation offers a base of insight, which facilitates the organization to efficiently process, interpret, and act on information about external events and trends. Intrinsically, it can be hypothesized that:

Hypothesis 5: An organization's knowledge management orientation is positively related to market orientation.

\subsection{Mediating role of market orientation}

In prior study, market orientation is a missing bond between KMO and the organizational performance (Hurley \& Hult, 1998). Established in the resource-based view (Wernerfelt, 1984), the logic for this declaration is that neither an organization's KMO nor its MO can be raised to a "strategic resource" autonomously. Rather, the real combination of both in an interlinked manner where KMO works as the inside-out basis for the outside-in intensive MO (Day, 1999) - is essential to accomplish a strategic asset that is rare, valuable, unique, and challenging to substitute (Barney, 1991). Some organizations develop a distinct ability of properly integrating, adapting, and reconfiguring external and internal business knowledge, resources, abilities, skills and functional competencies to match the requirements of a fluctuating atmosphere and thus enjoy a competitive differential benefit. Across organizations, this convergence emerges in inimitable and unique ways (Dierickx \& Cool, 1989). Other organizations attempt to align inside-out and outside-in processes, and their performance decline because this lack of fit compels their capability to counter to the market trends and events (Day, 1994). 
To be more specific, we mention that on one hand, knowledge management orientation may be deliberated the organization's pre-eminent expertise, and the key factor of all other capabilities and competencies (Devece et al., 2017; Lei, Slocum Jr, \& Pitts, 1997). On the other, an organization's positional advantage lies in providing customer value, through either a differentiation strategy or low-cost policy or a combination of both (Day \& Wensley, 1988). Basically, an organization's capability to grab the pulse of the market and the competition, and align its knowledge base to counter to the market environments, is a vital source of prospective competitive differential advantage (Aaker, 1989; Kasim et al., 2018). Such responses can not be achieved without associating the inside-out dedicated knowledge management orientation to the outside-in paradox of market orientation through the "spanning processes" discoursed by Day (1994). It is inadequate to develop knowledge management orientation abilities, which are entrenched in the organization's fabric; an organization must also have a system to enterprise knowledge management orientation (Mahoney \& Pandian, 1992; Naidoo, 2010). We propose that market orientation is a missing association in knowledge management outlines - the outside-in process, which transforms knowledge management orientation into organizational performance. Hence, it can be hypothesized that:

Hypothesis 6: Market orientation mediates the relationship of knowledge management orientation and organizational performance.

\subsection{Mediating role of organizational innovation}

The KMO has a significant impact on converting the power of organizational knowledge into organizational innovation (Kör \& Maden, 2013). Innovation is vital for organizational performance to acquire long-term viable competitive differential advantage (Standing \& Kiniti, 2011). Gunday et al. (2011) observed a optimistic association between non-technological innovation and organizational performance through an experimental research comprising Turkish manufacturing organizations. Atalay, Anafarta, and Sarvan (2013) examined the association between organizational innovation and its performance in the Turkish automotive supplier industry and exhibited that technological innovation had a substantial and positive influence on organizational performance. Jiménez-Jiménez and Sanz-Valle (2011) in their study, observed a positive association among knowledge management, organizational innovation and organizational performance. An allied outcome was sustained by the research of Calantone, Cavusgil, and Zhao (2002), who exposed that organizational innovation is positively associated with organizational performance in the manufacturing and service industries of United States. According to the results of these scholars, innovation ability of an organization is a wealth, which leads to better organizational performance. By the end of the 1990s, references to the KMO and organizational innovation in the modern management journals were common for organizational performance (Nelson \& McCann, 2010). Whereas numerous studies highlighted that organizational performance was principally affected by its knowledge management orientation (Li, Zhou, Zhou, \& You, 2015; Wang \& Wang, 2012) and business innovation (Artz, Norman, Hatfield, \& Cardinal, 2010; Gunday et al., 2011), some researchers connected the association between the knowledge management process and organizational innovation to organizational performance (Darroch, 2005; Mojtahedzadeh, 2014).

There is sufficient experiential proof to support the observation that an organization with a knowledge management orientation is probable to use resources more proficiently, more innovative and have improved performance (Darroch, 2003). For instance, Urgal, Quintás, and Arévalo-Tomé (2013) studied a positive influence of 
knowledge resources on an organization's innovation performance and an indirect impact on the innovation ability. Their results demonstrate how organizations can manage the knowledge resources for improving their performance based on their innovation. The contemporary research is pertinent because of its intent to tie innovation to the association between the KMO and organizational performance. In the research of Uhlaner, van Stel, Meijaard, and Folkeringa (2007), knowledge creation and knowledge absorption were observed to be imperative to the innovation success and business performance. Likewise, the research of Nawaz, Hassan, and Shaukat (2014) established that knowledge management expedited an organization's innovation that resulted in improved organizational performance. Yang (2010) focused on process innovation, while a few researchers examined the association between product innovation and organizational performance and observed a positive and significant association (Mitrega et al., 2017; Naranjo-Valencia, Jiménez-Jiménez, \& Sanz-Valle, 2016). Several researchers claim that marketing innovation increase organizational performance by conveying supplementary revenue to the organization and hence absolutely impact an organization's differential advantage (Johne \& Davies, 2000; Naidoo, 2010). To contribute to the literature gap, the contemporary research examines the mediating mechanism of organizational innovation in the association between the knowledge management orientation and organizational performance. Based on the above-mentioned empirical and theoretical results in the literature, the following hypothesis is anticipated:

Hypothesis 7: Organizational innovation mediates the relationship of knowledge management orientation and organizational performance.

\section{Research methodology}

\subsection{Population, sampling and procedures}

The hypothetical deductive methodology was selected for this study. Descriptive and causal study is carried out to lead and to finalize the study instrument. Telecom companies of Pakistan were targeted for this study. Telecom Sector is a fast-growing segment of Pakistan. Pakistan has been selected as a concentration of present research due to the complexity of the operating atmosphere of telecom sector. The sample for this study contains PTCL, Telenor, Mobilink, Ufone, Zong, and Warid from Telecom Sector. Mobilink, PTCL and Ufone are national, whereas Zong, Warid and Telenor are working as multinational organizations. The convenient sampling technique was used for this study. The questionnaires in number of 400 were dispersed amongst the managerial level employees. The Confirmatory Factor Analysis (CFA) was performed with AMOS (18.0) version to evaluate validity of the study instrument. The relationship among variables was analyzed with AMOS through Structural Equation Model (SEM) and finally, anticipated hypotheses were verified by the analysis of Structural Equation Model.

\subsection{Instrument and variable measurement}

The survey-based questionnaire was used for this particular research. The five-point likert scale with response choices ranging from 5 (five) "strongly agree" to 1 (one) "strongly disagree" was exercised for analysis purpose. The instrument comprised of two valuable parts. The part one contained demographic detail of target respondents and part two had questions related to the research variables. 
To measure knowledge management orientation, the scale of Wang et al. (2008) was used. This scale comprised of four constructs of knowledge management orientation. These constructs were organizations' memory (OM), knowledge absorption (KA), knowledge sharing (KS), and knowledge receptivity (KR). Four items were used to measure knowledge sharing and organizational memory. To measure Knowledge receptivity five items were used.

Scale of Jiménez-Jiménez and Sanz-Valle (2011) was used for the measurement of organizational innovation. The two fundamental types of innovation (administrative and technical innovation) were used in this research. An administrative innovation contains four numbers of observational items, whereas technical innovation contained three items.

The scale of Navarro et al. (2010) was used for measuring market orientation. This scale comprised three items. This scale measured three dimensions of market orientation, for instance to collect information about markets, actions and information about any changes in the environment.

For measuring organizational performance, the scale of Chen and Liang (2011) was used. This scale measured five aspects of organizational performance, for example market share, production cost and rivals related performance plus organizational industry related performance, professed excellence of services and goods.

\subsection{Assessment of reliability and validity}

For assessment of reliability, Cronbach's Alpha was used. The cronbach's alpha values have range from 0.00 to 1.00 . The high value of Chronbach's Alpha shows greater reliability. Researchers considered that 0.60 as the minimum acceptable value of reliability (Jolibert \& Jourdan, 2006). In the CFA, originally validity of all constructs was verified by applying the Measurement Assessment Model Fit method to verify the association of dissimilar constructs. Ensuring about method of assessment, an association among variables was tested. Particularly applying the technique, the researcher was capable to identify how best all obvious variables regarding its construct have linkage with each other. The results of factor loadings are given in Table 2. By assessing measurement model with CFA, maximum likelihood (ML) of assessment was used (Hooper, Coughlan, \& Mullen, 2008).

CFA was used to check convergent and discriminant validity for assessing the construct validity. Convergent validity was verified according to the item loadings and average variance extracted (AVE). Table 1 exhibits the AVE values of all the study constructs, which is above 0.50. Factor loadings were observed as greater than 0.50 . Consequently, convergent validity was accomplished in the contemporary research. The method of Fornell and Larcker (1981) was used to institute the discriminant validity. According to the method of Fornell and Larcker (1981), the square root of the AVE must be higher than the correlation between the construct and the other constructs in order to accomplish discriminate validity. As shown in Table 1, square root of AVE (shown in the diagonal of correlation matrix) among constructs is greater than their inter-construct correlations, consequently, discriminant validity is established. Finally, Cronbach's alpha coefficient $(\alpha)$ and composite reliability (CR) were employed to check the reliabilities among the items of every construct. Table 1 shows that the $\alpha$ and CR values of all the study constructs were greater than 0.70 . Accordingly, reliability is established. 
Table 1

Values of $\alpha, \mathrm{AVE}, \mathrm{CR}$, and correlation matrix

\begin{tabular}{lccccccccccc}
\hline \multicolumn{1}{c}{ Constructs } & $\boldsymbol{\alpha}$ & $\mathbf{A V E}$ & $\mathbf{C R}$ & $\mathbf{1}$ & $\mathbf{2}$ & $\mathbf{3}$ & $\mathbf{4}$ & $\mathbf{5}$ & $\mathbf{6}$ & $\mathbf{7}$ & $\mathbf{8}$ \\
\hline Organization Memory (1) & .954 & 0.626 & 0.724 & $\mathbf{0 . 7 9 1}$ & & & & & & \\
Knowledge Sharing (2) & .780 & 0.731 & 0.768 & 0.441 & $\mathbf{0 . 8 5 4}$ & & & & & \\
Knowledge Absorption (3) & .841 & 0.612 & 0.890 & 0.449 & 0.532 & $\mathbf{0 . 9 1 7}$ & & & & \\
Knowledge Receptivity (4) & .710 & 0.603 & 0.790 & 0.536 & 0.590 & 0.539 & $\mathbf{0 . 8 4 2}$ & & & \\
Administration Innovation (5) & .689 & 0.728 & 0.819 & 0.581 & 0.647 & 0.573 & 0.463 & $\mathbf{0 . 8 3 0}$ & & \\
Technical Innovation (6) & .835 & 0.739 & 0.835 & 0.653 & 0.562 & 0.570 & 0.683 & 0.489 & $\mathbf{0 . 8 5 9}$ & \\
Market Orientation (7) & .877 & 0.805 & 0.827 & 0.619 & 0.519 & 0.509 & 0.467 & 0.450 & 0.401 & $\mathbf{0 . 8 9 7}$ & \\
Organizational Performance (8) & .802 & 0.736 & 0.807 & 0.524 & 0.532 & 0.671 & 0.481 & 0.468 & 0.467 & 0.485 & $\mathbf{0 . 8 5 7}$ \\
\hline
\end{tabular}

Table 2

Factor loading

\begin{tabular}{|c|c|c|c|}
\hline Constructs & & Items & Estimates \\
\hline \multirow{4}{*}{$\begin{array}{l}\text { Organizational } \\
\text { Memory }\end{array}$} & OM1 & $\begin{array}{l}\text { Our organization has system to capture and store ideas } \\
\text { and knowledge. }\end{array}$ & .831 \\
\hline & OM2 & $\begin{array}{l}\text { Our organization has system to codify and classify } \\
\text { thoughts in a design, which is easier to accumulate for } \\
\text { future use. }\end{array}$ & .702 \\
\hline & OM3 & $\begin{array}{l}\text { Information technology helps the procedures of } \\
\text { classifying, capturing, retrieving and storing, data plus } \\
\text { thoughts. }\end{array}$ & .821 \\
\hline & OM4 & $\begin{array}{l}\text { We have systems to codify and categorize ideas in a } \\
\text { format that is easier to save for future use. }\end{array}$ & .778 \\
\hline \multirow{4}{*}{$\begin{array}{l}\text { Knowledge } \\
\text { Sharing }\end{array}$} & KS1 & $\begin{array}{l}\text { Our organization has system and settings for } \\
\text { employees to share knowledge and learn from each } \\
\text { other in the organization. }\end{array}$ & .752 \\
\hline & $\mathrm{KS} 2$ & $\begin{array}{l}\text { Our employees share information and knowledge with } \\
\text { our managers. }\end{array}$ & .658 \\
\hline & KS3 & $\begin{array}{l}\text { Our employees share information and knowledge with } \\
\text { our subordinate. }\end{array}$ & .798 \\
\hline & KS4 & $\begin{array}{l}\text { Our employees often share their thoughts and ideas } \\
\text { with other individuals of similar significance, even if } \\
\text { they are based in diverse areas. }\end{array}$ & .831 \\
\hline \multirow{2}{*}{$\begin{array}{l}\text { Knowledge } \\
\text { Absorption }\end{array}$} & KA1 & $\begin{array}{l}\text { Our organization use information technology to access } \\
\text { a broad array of outdoor information and knowledge } \\
\text { on rivals and market changes, etc. }\end{array}$ & .731 \\
\hline & KA2 & $\begin{array}{l}\text { Through sharing information and knowledge, our } \\
\text { company often comes up with innovative thoughts and } \\
\text { ideas, which may be utilized to improve our } \\
\text { organization. }\end{array}$ & .788 \\
\hline
\end{tabular}




\begin{tabular}{|c|c|c|c|}
\hline & KA3 & $\begin{array}{l}\text { Our organization has network of knowledge sharing } \\
\text { with other firms on a accepted base. }\end{array}$ & .972 \\
\hline \multirow{4}{*}{$\begin{array}{l}\text { Knowledge } \\
\text { Receptivity }\end{array}$} & KR1 & $\begin{array}{l}\text { Our people hesitate to speak out their ideas as new } \\
\text { ideas have a tendency to be highly criticized or } \\
\text { ignored. }\end{array}$ & .864 \\
\hline & KR2 & $\begin{array}{l}\text { In our organization, we appraise ideas based on their } \\
\text { merits, no matter who comes up with the ideas. }\end{array}$ & .861 \\
\hline & KR3 & $\begin{array}{l}\text { In our company, we evaluate new ideas quickly on a } \\
\text { regular basis. }\end{array}$ & .748 \\
\hline & KR4 & $\begin{array}{l}\text { There is a common culture in our organization where } \\
\text { employees respect knowledge and knowledge } \\
\text { ownership. }\end{array}$ & .971 \\
\hline \multirow{6}{*}{$\begin{array}{l}\text { Administrative } \\
\text { Innovation }\end{array}$} & KR5 & $\begin{array}{l}\text { Employees who donate innovative ideas are invited to } \\
\text { participate in future development and execution of this } \\
\text { innovative idea. }\end{array}$ & .921 \\
\hline & AI1 & Novelty of the management systems. & .707 \\
\hline & AI2 & $\begin{array}{l}\text { Search of innovative management systems by } \\
\text { directives. }\end{array}$ & 697 \\
\hline & $\mathrm{AI} 3$ & $\begin{array}{l}\text { Pioneer disposition to initiate innovative management } \\
\text { systems, scale, process. }\end{array}$ & .779 \\
\hline & AI4 & $\begin{array}{l}\text { Efforts on innovation in terms of hours/person, teams } \\
\text { and training involved in innovation, scale. }\end{array}$ & .798 \\
\hline & TI1 & Number of new products or services introduced. & .911 \\
\hline \multirow{3}{*}{$\begin{array}{l}\text { Technical } \\
\text { Innovation }\end{array}$} & TI2 & $\begin{array}{l}\text { Pioneer disposition } \\
\text { products/services. }\end{array}$ & .784 \\
\hline & TI3 & $\begin{array}{l}\text { Research and development expenditure in new } \\
\text { products or services, scale }\end{array}$ & .707 \\
\hline & MO1 & $\begin{array}{l}\text { In our organization, we systematically collect } \\
\text { information about the markets (needs, desires, level of } \\
\text { satisfaction with our products, etc.). }\end{array}$ & .961 \\
\hline \multirow[t]{3}{*}{$\begin{array}{l}\text { Market } \\
\text { Orientation }\end{array}$} & $\mathrm{MO} 2$ & $\begin{array}{l}\text { In our organization, we systematically collect } \\
\text { information about our rivals' actions in the markets } \\
\text { (price policy, product, market segments targeted, etc.). }\end{array}$ & .875 \\
\hline & MO3 & $\begin{array}{l}\text { In our organization, we systematically collect } \\
\text { information about any changes in the environment } \\
\text { (technologies, regulations, economic aspects, etc.). }\end{array}$ & .917 \\
\hline & OP1 & $\begin{array}{l}\text { Perceived quality of products and services relative to } \\
\text { competitors. }\end{array}$ & .807 \\
\hline \multirow{4}{*}{$\begin{array}{l}\text { Organizational } \\
\text { Performance }\end{array}$} & $\mathrm{OP} 2$ & Production cost relative to competitors & .748 \\
\hline & OP3 & Market share relative to competitors & .856 \\
\hline & OP4 & Performance relative to competitors & .748 \\
\hline & OP5 & $\begin{array}{l}\text { Organizational performance relative to industry } \\
\text { average }\end{array}$ & .890 \\
\hline
\end{tabular}




\section{Results of the study}

\subsection{Analysis of demographics}

Table 3 shows the respondents' demographic profile. According to the Table 3, there were 343 individuals, out of them 213 were male respondents, 130 were female workers. Explicitly, sample was comprised of $67 \%$ of male as well as $33 \%$ of female. The table describes that $43 \%$ of respondents were in the age bracket of $41-50,17 \%$ were in the age bracket of 21-30. There were $40 \%$ responders in the age bracket of 31-40.

Table 3

Demographic profile of respondents

\begin{tabular}{lccc}
\hline Demographic & Category & Frequency & Percentage \\
\hline \multirow{2}{*}{ Gender } & Male & 213 & 67 \\
& Female & 130 & 37 \\
Age & $21-30$ & 57 & 17 \\
& $31-40$ & 139 & 40 \\
Marital Status & $41-50$ & 147 & 43 \\
& Married & 189 & 55 \\
Qualification & Unmarried & 154 & 45 \\
& Graduate & 198 & 58 \\
& Master & 128 & 37 \\
\multirow{2}{*}{ Service Period } & PhD's & 17 & 05 \\
& $1-2$ & 117 & 34 \\
Total & $3-5$ & 81 & 24 \\
& $6-10$ & 86 & 25 \\
\hline
\end{tabular}

Table displays that $55 \%$ employees were married and $45 \%$ were unmarried. Explicitly, 58\% respondents were Graduate. $37 \%$ were Master, and $05 \%$ were PhDs. The table shows that most employees had 1-2 year tenure in the current organization. As a percentage, $34 \%$ had 1-2 years' experience in current organization and $24 \%$ had $3-5$ years' experience, $25 \%$ had 6-10 years' service and 17\% had more than ten-year service in the present organization.

\subsection{Hypotheses testing}

To test the hypotheses, a structural equation modeling method was used through AMOS 18, Fig. 2 shows the path diagram of the proposed model. The results of the study in the Table 4 report regression estimate, regression path, critical ratio, standard error, significance values, and designate of conjectured association. The particular result designates significant and positive influence of knowledge management orientation on organizational performance $(\beta=.41, \quad P<0.050$, Hypothesis-1). This displays that knowledge management orientation increases organizational performance by $41 \%$ roughly. The critical ratio (4.726) discloses that KMO is considered as a significant factor of organizational performance. The analysis further demonstrates that the KMO is 
positively linked to organizational innovation, as is clear from the table that $\beta=.35$ at $P<$ 0.050 . Hence, Hypothesis 2 is accepted. Moreover, KMO is positively associated with market orientation $(\beta=.40, \quad P<0.050)$, thus providing support for Hypothesis 3 . Hypothesis 4 postulates that organizational innovation is positively and significantly related with organizational performance and the results support as $\beta$ value is .27 at $P<$ 0.050 . To check the impact of market orientation on organizational performance, it was found that market orientation $(\beta=.49, P<0.050)$ had a positive impact on organizational performance. Consequently, Hypothesis 5 was also supported.

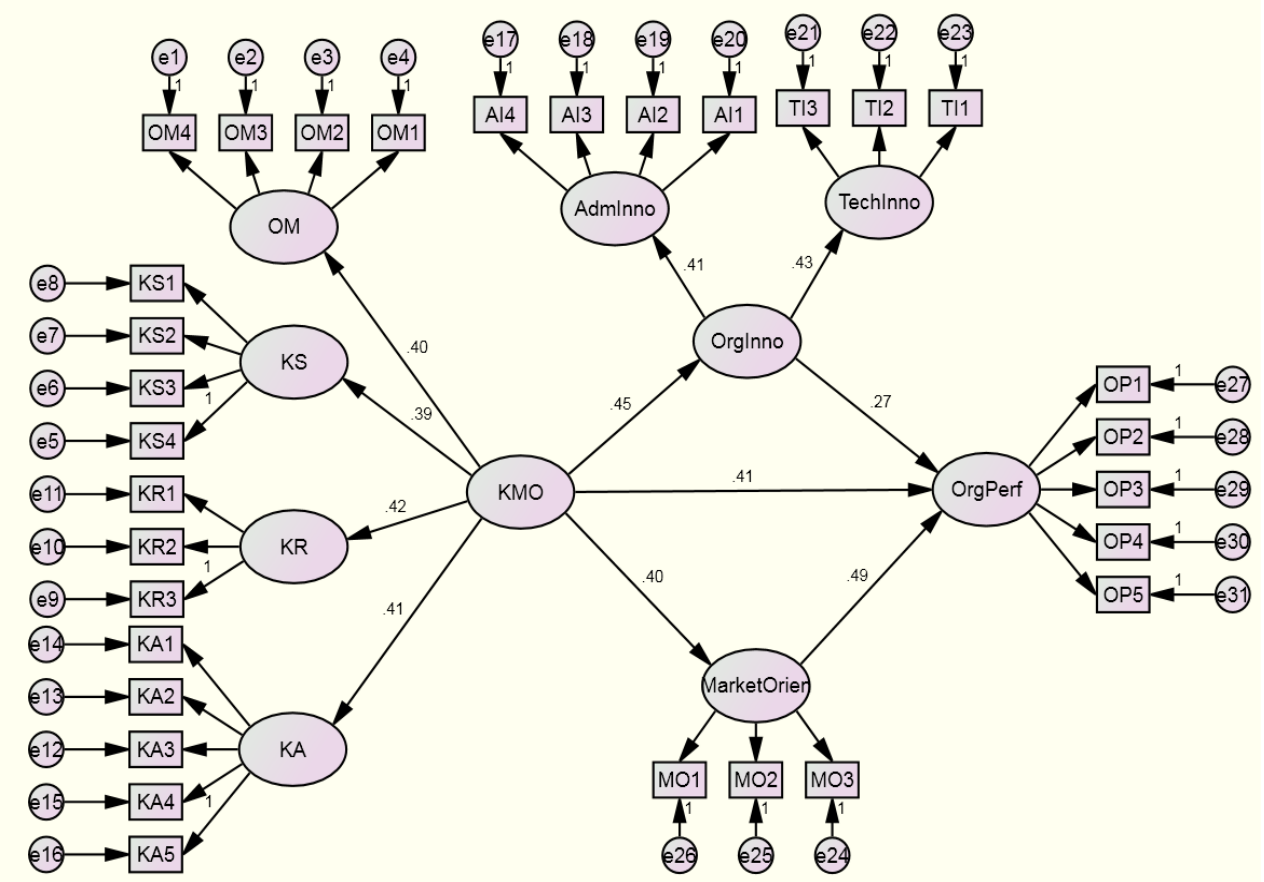

Note. $\mathrm{OM}=$ Organizational memory, $\mathrm{KS}=$ Knowledge sharing, $\mathrm{KR}=$ Knowledge receptivity,

$\mathrm{KA}=$ Knowledge absorption, AdmInno=Administrative innovation, TechInno=Technical innovation, OrgInno=Organizational Innovation, MarketOrien=Market orientation, OrgPerf=Organizational Performance.

Fig. 2. Path diagram of proposed model

Table 4

Regression weights

\begin{tabular}{|c|c|c|c|c|c|c|c|c|}
\hline \multicolumn{4}{|c|}{ Hypothesis } & \multirow{2}{*}{$\begin{array}{c}\text { Estimates } \\
.409\end{array}$} & \multirow{2}{*}{$\begin{array}{r}\text { S.E. } \\
.095\end{array}$} & \multirow{2}{*}{$\frac{\text { C.R. }}{4.726}$} & \multirow{2}{*}{$\frac{\text { P. }}{* * *}$} & \multirow{2}{*}{$\begin{array}{l}\text { Remarks } \\
\text { Supported }\end{array}$} \\
\hline $\mathrm{H} 1$ & Performance & $<--$ & KMO & & & & & \\
\hline $\mathrm{H} 2$ & Innovation & $<---$ & KMO & .452 & .108 & 4.185 & $* * *$ & Supported \\
\hline $\mathrm{H} 3$ & $\begin{array}{l}\text { Market } \\
\text { Orientation }\end{array}$ & $<--$ & KMO & .403. & .053 & 7.603 & $* * *$ & Supported \\
\hline $\mathrm{H} 4$ & Performance & $<--$ & Innovation & .271 & .058 & 4.672 & $* * *$ & Supported \\
\hline H5 & Performance & $<---$ & $\begin{array}{l}\text { Market } \\
\text { Orientation }\end{array}$ & .491 & .059 & 14.700 & $* * *$ & Supported \\
\hline
\end{tabular}


To check the mediating effect (Hypothesis 6 and Hypothesis 7), we used the mediation testing technique developed by Baron and Kenny (1986). The results demonstrate that market orientation and organizational innovation partially mediated the KMO - organizational performance relationship. Overall, all the study hypotheses were accepted in the contemporary research.

The results of Table 5 indicate Model Fitness Index, since the significance value regression path essentially means model was fit, the scholar has to go through model fit index given in AMOS results. The table also exposes seven model-fitness criterions. The model of Chi Square and linked considerable values show that this particular condition satisfies the lowest condition of model fitness, since the significance values are less than level of significance $(P<0.050)$ demonstrating discrepancy factors in the model (Tabachnick \& Fidell, 2007). One more fitness of measures is the goodness of the Fit index (GFI), with the help of convention to value for GFI equivalent to or may be greater 0.90 is good (Lomax \& Schumacker, 2004). The condition accomplishes the least accepted value of Model Fit (GFI > 0.90) and AGFI is variant regarding goodness to fit that adjusted goodness of fit index to degree of freedom. Further criterion contains CFI (Comparative-fit index) that is modified form of NFI (norm-fit index). The recommended value for NFI and CFI is equal or may greater 0.90. RMSEA (root-mean square-error of approximation) enlightens to optimally selected constraints would conform to population co-variance matrix. RMSEA value below 0.08 demonstrates good-fit of the model (Hooper et al., 2008). Based upon the previously mentioned criterion, model fit index meets the criteria of Model-fitness.

Table 5

Structural equation model fit measures

\begin{tabular}{lccccccccc}
\hline Constructs & Chi & D.F & $\begin{array}{c}\text { Chi/ } \\
\text { D.F }\end{array}$ & GFI & IFI & CFI & NFI & AGFI & RMSEA \\
\hline Model & 93.659 & 21.13 & 4.4 & .904 & .917 & .941 & .927 & .928 & .043 \\
$\begin{array}{l}\text { Traditional Cut off } \\
\text { Criteria }\end{array}$ & & & $\leq 5$ & $\geq 0.90$ & $\geq 0.90$ & $\geq 0.90$ & $\geq 0.90$ & $\geq 0.90$ & $\leq 0.08$ \\
\hline
\end{tabular}

Note. D.F. = Degree- of-Freedom, G.F.I. = Goodness- of-Fit-Index, I.F.I. = Incremental-Fit-Index, C.F.I. $=$ Comparative-Fit-Index, N.F.I. $=$ Normated-Fit-Index, A.G.F.I. $=$ Adjusted-Goodness-of-Fit Index, R.M.S.E.A. = Root-Mean-Square-Error-of-Approximation.

\section{Discussion}

This research examined a comprehensive model, which clearly furnishes the role of different important variables that in previous study established only limited and independent consideration. The key results of this study are argued as follows.

First, the outcomes demonstrate that the association between knowledge management orientation and organizational innovation is significant and positive. These results underline the important role of knowledge management orientation in increasing innovation of the business environment (Chen \& Huang, 2009). Second, the results signify that KMO would influence organizational performance optimistically. It demonstrates that with more knowledge management orientation in companies, there is more organizational performance ability. Third, the results point out that there is enough proof to sustain a link between organizational innovation and organization performance. Fourth, the key hypothetical contribution of contemporary study is the market orientation 
and organizational innovation as the mediating effect between KMO and business performance. Observed support demonstrated that the association between KMO and innovation is positive and significant. Accordingly, the present research contributes the markets' orientation causes an association amongst organizational performance and knowledge management orientation. It may be narrated that knowledge must execute via market orientation and innovation to increase organizational performance. Organizational performance would increase if an organization can employ market orientation in knowledge intensive business (Wang et al., 2009). The accelerating rates of the organizational innovation improves the development regarding quality of products, market share as well as organizational performance (Ballot et al., 2015). In general, based on the contemporary study results, we can say that the improvement of knowledge can play an important role in cultivating innovations, market orientation and for improvement of organizational performance.

Moreover, when knowledge is acknowledged, attained, and stored, organizations can execute this knowledge to investigate troubles and generate resolutions, thus creating a composition for assisting proficiency and usefulness. In the contemporary vibrant atmosphere, organizations need to obtain, generate, save, share, and enforce new knowledge to make a tactical decision, which may guide to improvement in output, employee performance, work relations, innovation, and customer satisfaction. Therefore, telecom managers must be dedicated to providing an accommodating atmosphere and culture that motivate the workforce and managers to execute the knowledge management practices, to improve the business performance.

It is obvious from the present study that lack of a suitable system of knowledge management in organization hinders an effective design and dissemination of market knowledge and accordingly suitable response on this knowledge. In contrast, winning knowledge management orientation executed in an organization builds circumstances for processing, interpreting and using knowledge about market trend and actions. Therefore, integration of knowledge management and market orientation is a significant ability and improve the viable location of an organization.

Today, customers of the organizations are very educated, knowledgeable and more demanding as compared to the customers of before. Therefore, responses to customers' needs and shifting market circumstances have become significant for the victory of organizations and call for introduction of the new goods and services together along with innovation capability for the business.

Certain to the regular relations between the aspects of organizational innovation, market orientation and organizational performance, we may debate that the pains of organizations to improve the gathering and utilization of market information and realization of market-oriented policy is particularly significant to businesses, which desire to get a competitive advantage. The outcomes of the contemporary research propose that knowledge management orientation can direct to organizations' innovation and market orientation, and increase performance of a firm as consistent with the results of Bajwa, Samad, Mumtaz, Kazmi, and Choudhary (2009), and Zack et al. (2009). Market orientation can guide to winning new product development activity.

It is recommended that market orientation as a driver of business market information giving out movement must be integrated into conceptualizations of innovation practice, because it usually survives on a variety illustrated by the amount to which businesses obtain, propagate and react to information attained from organizational customers, channel and rivals (Renko et al., 2009). Respond to market feedback may permit businesses to adjust productively in the external atmosphere that may be 
characterized both as vibrant and established. Consequently, market orientation is a foundation of innovative thoughts, opinions and inspiration to react to the atmosphere and increases business performance (Inoguchi, 2011).

\subsection{Conclusions}

This study discloses a positive relationship between market orientation, knowledge management orientation, organizational performance and organizational innovation of Telecom Sector in Pakistan. It also exposes that organizational innovation and market orientation have mediating role in the relationship of the organizational performance and KMO. In conclusion, fully employing the talents of every person will certainly provide answers to the major challenges, for example financial shortcoming in the organization. To conclude, knowledge is a precious asset for organizations hoping to attain advanced innovation and sustainable competitive advantage. The outlook of this research highlights the critical significance of the constructive role of market orientation while investigating the association of business performance and knowledge management orientation. Moreover, the conclusion of the research suggests that knowledge management, market orientation and organizational innovation are the key components for promoting the performance of the company.

Finally, the present research suggests that firms, which exploit these aspects effectively (knowledge management orientation, market orientation and innovation development) in their processes can expect positive innovation activities, which increase long-term performance of the organization. Moreover, the model provides a base to help both practitioners and researchers in understanding the essence of innovation and market orientation and how to relate it to corporate objectives. In knowledge base organizations, knowledge management orientation practices facilitate, and enhance organizational innovation and market orientation to produce higher business performance.

\subsection{Practical implications}

Telecom firms must recognize their customer's needs and wants and must have a complete emphasis on them and deployment of their resources to the best for the accomplishment of preferred objectives and goals. The scholar argued about the highlighting of shifting phenomenon, which was happening in the forceful competition of the market. Nowadays organizations have awareness of their customers and they are organizing the results that are promoting the modes of success.

Consumer orientation and rival orientation emerge to be dependent on an organization's competitive atmosphere. It proposes that whereas both customer orientation and rival orientation are critical for the common understanding of the market, they can offer a diverse variety of information for diverse types of choices and decision makers of the organizations. Furthermore, the result of this study is a strong indicator that market orientation is not even related to organizations with diverse approaches and for organizations in different environmental circumstances.

Moreover, managers should recognize the benefits of knowledge management practices, which can increase efficiency, productivity, employee performance, financial performance, innovation, work relations, and customer satisfaction. KM leadership must invest in external and internal resources in engaging of a suitable knowledge. Consequently, improved performance can be one of the long-term and strategic benefits of accomplishing KM best practices. Business managers should suitably transform the 
work culture and ecological conditions so that employees accept, support, commit to, and employ knowledge management practices in executing their activities.

\subsection{Recommendations and limitations}

We have come to know through the findings of the contemporary research that market orientation has optimistic influence on the business performance. The researcher also discovered a positive result that the market orientation would positively enhance the organizational performance. With the significance of all these factors' impact on the organizational performance, it is recommended that owing to the change of the global system, market orientation must be according to the necessities that enable the organization to assist their resources with improved execution of business policies they make high earnings to survive and success for the future.

The organizations should apply information technology to introduce new products and continuous training of employees to meet customer satisfaction. The businesses should pay more attention to the innovativeness in determining a firm's purposes, and reward those who are contributing to this process and giving fresh and innovative ideas. Moreover, organizations should adopt innovative practices and procedures before competitors and stabilize their position in the marketplace by adopting competitive approaches and strategies.

This particular research has few limitations. First limitation is that this research adopted a cross-sectional study. A longitudinal research to observe vibrant features regarding knowledge management orientation would offer results that are more vigorous. Second, contemporary study was done in the telecom sector of Pakistan. Further researches should investigate more organizations such as banking, education, medicines, etc. Third, some other variables like organizational culture, time management, and organizational learning may also be as mediating variables in the association between performance of an organization and knowledge management orientation. Hence, these factors may be investigated in future study.

\section{ORCII}

Irfan Ulah (10) https://orcid.org/0000-0002-0285-104X

Bilal Mirza (iD https://orcid.org/0000-0003-4274-6014

Abdul Rauf Kashif (미 https://orcid.org/0000-0001-6349-2178

Farrukh Abbas (10) https://orcid.org/0000-0001-9623-3981

\section{References}

Aaker, D. A. (1989). Managing assets and skills: The key to a sustainable competitive advantage. California Management Review, 31(2), 91-106.

Adams, R., Jeanrenaud, S., Bessant, J., Denyer, D., \& Overy, P. (2016). Sustainability-oriented innovation: A systematic review. International Journal of Management Reviews, 18(2), 180-205.

Argote, L., McEvily, B., \& Reagans, R. (2003). Managing knowledge in organizations: An integrative framework and review of emerging themes. Management Science, 49(4), 571-582. 
Artz, K. W., Norman, P. M., Hatfield, D. E., \& Cardinal, L. B. (2010). A longitudinal study of the impact of R\&D, patents, and product innovation on firm performance. Journal of Product Innovation Management, 27(5), 725-740.

Atalay, M., Anafarta, N., \& Sarvan, F. (2013). The relationship between innovation and firm performance: An empirical evidence from Turkish automotive supplier industry. Procedia-Social and Behavioral Sciences, 75, 226-235.

Bajwa, I. S., Samad, A., Mumtaz, S., Kazmi, R., \& Choudhary, A. (2009). BPM meeting with SOA: A customized solution for small business enterprises. In Proceedings of the 2009 International Conference on Information Management and Engineering (pp. 677-682). IEEE.

Ballot, G., Fakhfakh, F., Galia, F., \& Salter, A. (2015). The fateful triangle: Complementarities in performance between product, process and organizational innovation in France and the UK. Research Policy, 44(1), 217-232.

Bamberger, P. A., Biron, M., \& Meshoulam, I. (2014). Human resource strategy: Formulation, implementation, and impact. Routledge.

Baregheh, A., Rowley, J., \& Sambrook, S. (2009). Towards a multidisciplinary definition of innovation. Management Decision, 47(8), 1323-1339.

Barney, J. (1991). Firm resources and sustained competitive advantage. Journal of Management, 17(1), 99-120.

Baron, R. M., \& Kenny, D. A. (1986). The moderator-mediator variable distinction in social psychological research: Conceptual, strategic, and statistical considerations. Journal of Personality and Social Psychology, 51(6), 1173-1182.

Bhuian, S. N. (1997). Exploring market orientation in banks: An empirical examination in Saudi Arabia. Journal of Services Marketing, 11(5), 317-328.

Birkinshaw, J., Hamel, G., \& Mol, M. J. (2008). Management innovation. Academy of Management Review, 33(4), 825-845.

Brewer, P. D., \& Brewer, K. L. (2010). Knowledge management, human resource management, and higher education: A theoretical model. Journal of Education for Business, 85(6), 330-335.

Calantone, R. J., Cavusgil, S. T., \& Zhao, Y. (2002). Learning orientation, firm innovation capability, and firm performance. Industrial Marketing Management, $31(6), 515-524$.

Castaneda, D. I., \& Durán, W. F. (2018). Knowledge sharing in organizations: Roles of beliefs, training, and perceived organizational support. Knowledge Management \& ELearning, 10(2), 148-162.

Certo, S. T., Moss, T. W., \& Short, J. C. (2009). Entrepreneurial orientation: An applied perspective. Business Horizons, 52(4), 319-324.

Chang, W. J. A., \& Huang, T. C. (2005). Relationship between strategic human resource management and firm performance: A contingency perspective. International Journal of Manpower, 26(5), 434-449.

Chen, C.-J., \& Huang, J.-W. (2009). Strategic human resource practices and innovation performance-The mediating role of knowledge management capacity. Journal of Business Research, 62(1), 104-114.

Chen, D. N., \& Liang, T. P. (2011). Knowledge evolution strategies and organizational performance: A strategic fit analysis. Electronic Commerce Research and Applications, 10(1), 75-84.

Chen, Y. C., Li, P. C., Evans, K. R., \& Arnold, T. J. (2017). Interaction orientation and product development performance for Taiwanese electronics firms: The mediating role of market-relating capabilities. Journal of Product Innovation Management, 34(1), 13-34.

Cohen, W. M., \& Levinthal, D. A. (1990). Absorptive capacity: A new perspective on 
learning and innovation. Administration Science Quarterly, 35(1), 128-152.

Cooper, J. R. (1998). A multidimensional approach to the adoption of innovation. Management Decision, 36(8), 493-502.

Damanpour, F., \& Evan, W. M. (1984). Organizational innovation and performance: The problem of "organizational lag”. Administrative Science Quarterly, 29(3), 392-409.

Damanpour, F., \& Gopalakrishnan, S. (2001). The dynamics of the adoption of product and process innovations in organizations. Journal of Management Studies, 38(1), 4565 .

Damanpour, F., Szabat, K. A., \& Evan, W. M. (1989). The relationship between types of innovation and organizational performance. Journal of Management Studies, 26(6), 587-602.

Darroch, J. (2003). Developing a measure of knowledge management behaviors and practices. Journal of Knowledge Management, 7(5), 41-54.

Darroch, J. (2005). Knowledge management, innovation and firm performance. Journal of Knowledge Management, 9(3), 101-115.

Davis, S. M. (1984). Managing corporate culture. Cambridge, MA: Ballinger.

Day, G. S. (1994). The capabilities of market-driven organizations. The Journal of Marketing, 58(4), 37-52.

Day, G. S. (1999). The market driven organization: Understanding, attracting, and keeping valuable customers. New York, NY: The Free Press.

Day, G. S., \& Wensley, R. (1988). Assessing advantage: A framework for diagnosing competitive superiority. The Journal of Marketing, 52(2), 1-20.

de Guimarães, J. C. F., Severo, E. A., \& de Vasconcelos, C. R. M. (2018). The influence of entrepreneurial, market, knowledge management orientations on cleaner production and the sustainable competitive advantage. Journal of Cleaner Production, 174, 1653-1663.

Deshpande, R., \& Webster Jr, F. E. (1989). Organizational culture and marketing: Defining the research agenda. The Journal of Marketing, 53(1), 3-15.

Devece, C., Llopis-Albert, C., \& Palacios-Marqués, D. (2017). Market orientation, organizational performance, and the mediating role of crowdsourcing in knowledge-based firms. Psychology \& Marketing, 34(12), 1127-1134.

Dierickx, I., \& Cool, K. (1989). Asset stock accumulation and the sustainability of competitive advantage: Reply. Management Science, 35(12), 1504-1511.

Donate, M. J., \& de Pablo, J. D. S. (2015). The role of knowledge-oriented leadership in knowledge management practices and innovation. Journal of Business Research, 68(2), 360-370.

Eger, L. (2018). How people acquire knowledge from a web page: An eye tracking study. Knowledge Management \& E-Learning, 10(3), 350-366.

Emerson, L. C., \& Berge, Z. L. (2018). Microlearning: Knowledge management applications and competency-based training in the workplace. Knowledge Management \& E-Learning, 10(2), 125-132.

Fang, Z., \& Chang, Y. (2016). Energy, human capital and economic growth in Asia Pacific countries - Evidence from a panel cointegration and causality analysis. Energy Economics, 56, 177-184.

Farooq, M. (2018, April 27). Economic survey 2017-18: Telecom sector revenues touched Rs235.5 billion in FY 2017-18. Pakistan Today Profit. Retrieved from https://profit.pakistantoday.com.pk/2018/04/27/economic-survey-2017-18-telecomsector-revenues-touched-rs235-5-billion-in-fy-2017-18/

Farooq, R., \& Vij, S. (2018). Linking entrepreneurial orientation and business performance: Mediating role of knowledge management orientation. Pacific Business Review International, 10(8), 174-183.

Fornell, C., \& Larcker, D. F. (1981). Evaluating structural equation models with 
unobservable variables and measurement error. Journal of Marketing Research, 18(1), 39-50.

Gunday, G., Ulusoy, G., Kilic, K., \& Alpkan, L. (2011). Effects of innovation types on firm performance. International Journal of Production Economics, 133(2), 662-676.

Hansen, M. T., Mors, M. L., \& Løvås, B. (2005). Knowledge sharing in organizations: Multiple networks, multiple phases. Academy of Management Journal, 48(5), 776793.

Herrera, L., Muñoz-Doyague, M. F., \& Nieto, M. (2010). Mobility of public researchers, scientific knowledge transfer, and the firm's innovation process. Journal of Business Research, 63(5), 510-518.

Hooper, D., Coughlan, J., \& Mullen, M. (2008). Structural equation modelling: Guidelines for determining model fit. Electronic Journal of Business Research Methods, 6(1), 53-60.

Hurley, R. F., \& Hult, G. T. M. (1998). Innovation, market orientation, and organizational learning: An integration and empirical examination. The Journal of Marketing, 62(3), 42-54.

Hussein, A. S., Rahayu, M., \& Prabandari, S. P. (2017). Revisiting the dimensions of knowledge management orientation behavior in Indonesia creative industry. International Research Journal of Business Studies, 9(2), 63-73.

Hwang, G.-J., \& Xie, H. (2018). Review and trend analysis of knowledge management and e-learning research. Knowledge Management \& E-Learning, 10(4), 371-374.

Hyun, S. (2018). Innovation and performance. Doctoral dissertation, University of Calgary, Alberta, Canada.

Inoguchi, T. (2011). Japanese ideas of Asian regionalism. Japanese Journal of Political Science, 12(2), 233-249.

Ireland, R. D., Reutzel, C. R., \& Webb, J. W. (2005). Entrepreneurship research in AMJ: What has been published, and what might the future hold? Academy of Management Journal, 48(4), 556-564.

Jiménez-Jiménez, D., \& Sanz-Valle, R. (2011). Innovation, organizational learning, and performance. Journal of Business Research, 64(4), 408-417.

Johne, A., \& Davies, R. (2000). Innovation in medium-sized insurance companies: How marketing adds value. International Journal of Bank Marketing, 18(1), 6-14.

Jolibert, A., \& Jourdan, P. (2006). Marketing reseach: Méthodes de recherche et d'études en marketing. Paris: Dunod.

Kasim, A., Ekinci, Y., Altinay, L., \& Hussain, K. (2018). Impact of market orientation, organizational learning and market conditions on small and medium-size hospitality enterprises. Journal of Hospitality Marketing \& Management, 27(7), 855-875.

Kingston, J., \& Macintosh, A. (2000). Knowledge management through multiperspective modelling: Representing and distributing organizational memory. Knowledge-Based Systems, 13(2/3), 121-131.

Kirca, A. H., Jayachandran, S., \& Bearden, W. O. (2005). Market orientation: A metaanalytic review and assessment of its antecedents and impact on performance. Journal of Marketing, 69(2), 24-41.

Kohli, A. K., Jaworski, B. J., \& Kumar, A. (1993). MARKOR: A measure of market orientation. Journal of Marketing Research, 30(4), 467-477.

Kör, B., \& Maden, C. (2013). The relationship between knowledge management and innovation in Turkish service and high-tech firms. International Journal of Business and Social Science, 4(4), 293-304.

Krammer, S. M. S. (2017). Science, technology, and innovation for economic competitiveness: The role of smart specialization in less-developed countries. Technological Forecasting and Social Change, 123, 95-107. 
Lee, J.-N. (2001). The impact of knowledge sharing, organizational capability and partnership quality on IS outsourcing success. Information \& Management, 38(5), 323-335.

Lei, D., Slocum Jr, J. W., \& Pitts, R. A. (1997). Building cooperative advantage: Managing strategic alliances to promote organizational learning. Journal of World Business, 32(3), 203-223.

Li, Y., Zhou, X., Zhou, N., \& You, J. (2015). The complementary effect of knowledge management strategies on firm performance. In Proceedings of the 21st International Conference on Industrial Engineering and Engineering Management (pp. 649-653).

Li, Y.-H., Huang, J.-W., \& Tsai, M.-T. (2009). Entrepreneurial orientation and firm performance: The role of knowledge creation process. Industrial Marketing Management, 38(4), 440-449.

Liao, S.-H., Fei, W.-C., \& Chen, C.-C. (2007). Knowledge sharing, absorptive capacity, and innovation capability: An empirical study of Taiwan's knowledge-intensive industries. Journal of Information Science, 33(3), 340-359.

Lin, C.-Y. (2007). Factors affecting innovation in logistics technologies for logistics service providers in China. Journal of Technology Management in China, 2(1), 22-37.

Lin, H.-F., \& Lee, G.-G. (2005). Impact of organizational learning and knowledge management factors on e-business adoption. Management Decision, 43(2), 171-188.

Liu, D., Gong, Y., Zhou, J., \& Huang, J. C. (2017). Human resource systems, employee creativity, and firm innovation: The moderating role of firm ownership. Academy of Management Journal, 60(3), 1164-1188.

Liu, X., \& White, R. S. (1997). The relative contributions of foreign technology and domestic inputs to innovation in Chinese manufacturing industries. Technovation, 17(3), 119-125.

Lomax, R. G., \& Schumacker, R. E. (2004). A beginner's guide to structural equation modeling. Psychology Press.

Mahoney, J. T., \& Pandian, J. R. (1992). The resource-based view within the conversation of strategic management. Strategic Management Journal, 13(5), 363380.

Manfredi Latilla, V., Frattini, F., Messeni Petruzzelli, A., \& Berner, M. (2018). Knowledge management, knowledge transfer and organizational performance in the arts and crafts industry: A literature review. Journal of Knowledge Management, $22(6), 1310-1331$.

Martinez-Martinez, A., Cegarra-Navarro, J.-G., Garcia-Perez, A., \& Wensley, A. (2019). Knowledge agents as drivers of environmental sustainability and business performance in the hospitality sector. Tourism Management, 70, 381-389.

Masa'deh, R., Shannak, R., Maqableh, M., \& Tarhini, A. (2017). The impact of knowledge management on job performance in higher education: The case of the University of Jordan. Journal of Enterprise Information Management, 30(2), 244-262.

Maughan, C. (2012). Organisational innovation: A review of the literature (CRC-REP Working Paper CW001). Alice Springs: Ninti One Limited.

Mavondo, F. T., Chimhanzi, J., \& Stewart, J. (2005). Learning orientation and market orientation: Relationship with innovation, human resource practices and performance. European Journal of Marketing, 39(11/12), 1235-1263.

Mitrega, M., Forkmann, S., Zaefarian, G., \& Henneberg, S. C. (2017). Networking capability in supplier relationships and its impact on product innovation and firm performance. International Journal of Operations \& Production Management, 37(5), 577-606.

Mojtahedzadeh, R. (2014). The effect of quality culture and organisational performance in Iran car manufacturing companies. Doctoral dissertation, Multimedia University, Malaysia. 
Moorman, C., \& Miner, A. S. (1997). The impact of organizational memory on new product performance and creativity. Journal of Marketing Research, 34(1), 91-106.

Morgan, N. A., Kaleka, A., \& Katsikeas, C. S. (2004). Antecedents of export venture performance: A theoretical model and empirical assessment. Journal of Marketing, 68(1), 90-108.

Naidoo, V. (2010). Firm survival through a crisis: The influence of market orientation, marketing innovation and business strategy. Industrial Marketing Management, 39(8), $1311-1320$.

Naranjo-Valencia, J. C., Jiménez-Jiménez, D., \& Sanz-Valle, R. (2016). Studying the links between organizational culture, innovation, and performance in Spanish companies. Revista Latinoamericana de Psicología, 48(1), 30-41.

Narver, J. C., \& Slater, S. F. (1990). The effect of a market orientation on business profitability. The Journal of Marketing, 54(4), 20-35.

Navarro, A., Acedo, F. J., Robson, M. J., Ruzo, E., \& Losada, F. (2010). Antecedents and consequences of firms' export commitment: An empirical study. Journal of International Marketing, 18(3), 41-61.

Nawaz, M. S., Hassan, M., \& Shaukat, S. (2014). Impact of knowledge management practices on firm performance: Testing the mediation role of innovation in the manufacturing sector of Pakistan. Pakistan Journal of Commerce \& Social Sciences, 8(1), 99-111.

Nelson, K., \& McCann, J. E. (2010). Designing for knowledge worker retention \& organization performance. Journal of Management and Marketing Research, 3: 1.

Nonaka, I., \& Takeuchi, H. (1995). The knowledge-creating company: How Japanese companies create the dynamics of innovation. Oxford university press.

Nonaka, I., Toyama, R., \& Konno, N. (2000). SECI, Ba and leadership: A unified model of dynamic knowledge creation. Long Range Planning, 33(1), 5-34.

Pérez-Luño, A., Valle Cabrera, R., \& Wiklund, J. (2007). Innovation and imitation as sources of sustainable competitive advantage. Management Research, 5(2), 71-82.

Popper, M., \& Lipshitz, R. (1998). Organizational learning mechanisms: A structural and cultural approach to organizational learning. The Journal of Applied Behavioral Science, 34(2), 161-179.

Rahman, M. S., Daud, N. M., \& Raman, M. (2018). Knowledge sharing behaviour among non-academic staff in higher learning institutes: The role of trust and perceived risk. Knowledge Management \& E-Learning, 10(1), 113-124.

Renko, M., Carsrud, A., \& Brännback, M. (2009). The effect of a market orientation, entrepreneurial orientation, and technological capability on innovativeness: A study of young biotechnology ventures in the United States and in Scandinavia. Journal of Small Business Management, 47(3), 331-369.

Riege, A. (2007). Actions to overcome knowledge transfer barriers in MNCs. Journal of Knowledge Management, 11(1), 48-67.

Scarbrough, H. (2003). Knowledge management, HRM and the innovation process. International Journal of Manpower, 24(5), 501-516.

Schulz, M., \& Jobe, L. A. (2001). Codification and tacitness as knowledge management strategies: An empirical exploration. The Journal of High Technology Management Research, 12(1), 139-165.

Schumpeter, J. A. (1934). Change and the entrepreneur. Cambridge, MA: Harvard University Press.

Shin, D., \& Konrad, A. M. (2017). Causality between high-performance work systems and organizational performance. Journal of Management, 43(4), 973-997.

Shujahat, M., Sousa, M. J., Hussain, S., Nawaz, F., Wang, M., \& Umer, M. (2019). Translating the impact of knowledge management processes into knowledge-based 
innovation: The neglected and mediating role of knowledge-worker productivity. Journal of Business Research, 94, 442-450.

Standing, C., \& Kiniti, S. (2011). How can organizations use wikis for innovation? Technovation, 31(7), 287-295.

Subramanian, A., \& Nilakanta, S. (1996). Organizational innovativeness: Exploring the relationship between organizational determinants of innovation, types of innovations, and measures of organizational performance. Omega, 24(6), 631-647.

Tabachnick, B. G., \& Fidell, L. S. (2007). Using multivariate statistics. Allyn \& Bacon/Pearson Education.

Tan, C. L., \& Nasurdin, A. M. (2010). Knowledge management effectiveness and technological innovation: An empirical study in the Malaysian manufacturing industry. Journal of Mobile Technologies, Knowledge and Society, Article ID 428053.

Teece, D. J. (1998). Capturing value from knowledge assets: The new economy, markets for know-how, and intangible assets. California Management Review, 40(3), 55-79.

Tidd, J., \& Bessant, J. R. (2018). Managing innovation: Integrating technological, market and organizational change. John Wiley \& Sons.

Tsai, W. (2001). Knowledge transfer in intraorganizational networks: Effects of network position and absorptive capacity on business innovation and performance. Academy of Management Journal, 44(5), 996-1004.

Tsai, W. (2002). Social structure of "coopetition" within a multiunit organization: Coordination, competition, and intraorganizational knowledge sharing. Organization Science, 13(2), 179-190.

Uhlaner, L., van Stel, A., Meijaard, J., \& Folkeringa, M. (2007). The relationship between knowledge management, innovation and firm performance: Evidence from Dutch SMEs (SCALES paper H200704). Scientific Analysis of Entrepreneurship and SMEs, Zoetermeer, The Netherlands.

Urgal, B., Quintás, M. A., \& Arévalo-Tomé, R. (2013). Knowledge resources and innovation performance: The mediation of innovation capability moderated by management commitment. Technology Analysis \& Strategic Management, 25(5), 543-565.

Van Den Bosch, F. A. J., Volberda, H. W., \& de Boer, M. (1999). Coevolution of firm absorptive capacity and knowledge environment: Organizational forms and combinative capabilities. Organization Science, 10(5), 551-568.

Van Raaij, E. M., \& Stoelhorst, J. W. (2008). The implementation of a market orientation: A review and integration of the contributions to date. European Journal of Marketing, 42(11/12), 1265-1293.

Wang, C. L., Ahmed, P. K., \& Rafiq, M. (2008). Knowledge management orientation: Construct development and empirical validation. European Journal of Information Systems, 17(3), 219-235.

Wang, C. L., Hult, G. T. M., Ketchen Jr, D. J., \& Ahmed, P. K. (2009). Knowledge management orientation, market orientation, and firm performance: An integration and empirical examination. Journal of Strategic Marketing, 17(2), 99-122.

Wang, Z., \& Wang, N. (2012). Knowledge sharing, innovation and firm performance. Expert Systems with Applications, 39(10), 8899-8908.

Wernerfelt, B. (1984). A resource-based view of the firm. Strategic Management Journal, $5(2), 171-180$.

Wiklund, J., \& Shepherd, D. (2003). Knowledge-based resources, entrepreneurial orientation, and the performance of small and medium-sized businesses. Strategic Management Journal, 24(13), 1307-1314.

Wofford, T. N. (2006). Creating the discipline of knowledge management: The latest in university research (Book review). Technical Communication, 53(1), 110-111.

Yang, J. (2010). The knowledge management strategy and its effect on firm performance: 
A contingency analysis. International Journal of Production Economics, 125(2), 215223.

Zack, M., McKeen, J., \& Singh, S. (2009). Knowledge management and organizational performance: an exploratory analysis. Journal of Knowledge Management, 13(6), 392-409.

Zahra, S. A., \& George, G. (2002). Absorptive capacity: A review, reconceptualization, and extension. Academy of Management Review, 27(2), 185-203.

Zheng, W., Yang, B., \& McLean, G. N. (2010). Linking organizational culture, structure, strategy, and organizational effectiveness: Mediating role of knowledge management. Journal of Business Research, 63(7), 763-771.

Zhou, K. Z. (2006). Innovation, imitation, and new product performance: The case of China. Industrial Marketing Management, 35(3), 394-402.

Zoghi, C., Mohr, R. D., \& Meyer, P. B. (2010). Workplace organization and innovation. Canadian Journal of Economics/Revue Canadienne d'économique, 43(2), 622-639. 